\title{
TÍCH HỢP GIS VÀ PHÂN TÍCH ĐA CHỈ TIÊU (MCA) THÀNH LẬP BẢN ĐỒ THOÁI HÓA ĐẤT TIỀM NĂNG TỈNH LÂM ĐỒNG
}

\author{
NGUYẼN TH!̣ THỦY, LƯU THÉ ANH \\ Viện Địa lý, Viện Hàn lâm Khoa học và Công nghệ Việt Nam
}

\section{Tóm tắt:}

Bản đồ thoái hóa đất tiềm năng sẽ cung cấp những thông tin quan trọng làm cơ sở ra quyết định trong quản lý, sử dụng đất hợp lý nhằm ngăn ngừa các quá trình thoái hóa đất. Thoái hóa đất tiềm năng có tương quan chặt chẽ với các nhân tố tự nhiên tham gia vào quá trình phát sinh đất như đá mẹ/mẫu chất, vỏ phong hóa, địa hình, thủy văn, khí hậu, thảm thực vật. Vai trò của mỗi yếu tố này gây ra thoái hoá là không ngang bằng nhau, đây là cơ sở để vận dụng phương pháp phân tích đa chỉ tiêu trong đánh giá thoái hóa đất tiềm năng của khu vực nghiên cứu. Phương pháp tích hợp GIS và phân tích đa chỉ tiêu (MCA) đã được ứng dụng để giải quyết bài toán thành lập bản đồ thoái hóa đất tiềm năng tỉnh Lâm Đồng. Kết quả nghiên cứu cho thấy, diện tích đất có tiềm thoái hóa nhẹ 130.398,3 ha (chiếm 13,3\% diện tích tự nhiên của tỉnh); tiềm năng thoái hóa trung bình có 534.608,1 ha (chiếm 54,7\%); tiềm năng thoái hóa mạnh có 290.557, 8 ha (chiếm 29,7\%) và tiềm năng thoái hóa rất mạnh có 21.790,3 ha (chiếm 2,3\%).

\section{Mở đầu}

Hiện nay, thoái hóa đất là vấn đề môi trường đáng lo ngại đối với nhiều quốc gia trên thế giới, đe dọa đến sử dụng đất bền vững và canh tác nông nghiệp. Các áp lực từ gia tăng dân số đã làm tăng các quá trình thoái hóa đất về quy mô và cường độ. Trên quan điểm sinh thái học, đất là một thực thể tự nhiên trải qua các quá trình phát sinh, phát triển và thoái hóa [1]. Thoái hóa đất tiềm năng là biểu hiện mức độ tiền đề của các yếu tố tự nhiên tham gia vào quá trình thoái hóa đất, với giả thiết đồng nhất thảm thực vật và chưa có tác động của con người. Đánh giá thoái hóa đất tiềm năng là xác định nguy cơ xảy ra các quá trình thoái hóa đất tự nhiên và mức độ nguy hiểm đối với môi trường [4]. Việc đánh giá và thành lập bản đồ thoái hóa đất tiềm năng sẽ cung cấp những thông tin quan trọng làm cơ sở đưa ra quyết định quản lý, sử dụng đất hợp lý nhằm ngăn ngừa thoái hóa đất, đặc biệt trong quy hoạch phát triển nông nghiệp. Tuy nhiên, khó khăn lớn nhất của bài toán đánh giá này là có nhiều yếu tố ảnh hưởng đến quá trình thoái hóa đất như: đá mẹ/mẫu chất, kiểu vỏ phong hoá, dạng địa hình và tính cực đoan của khí hậu (mưa tập trung, khô hạn kéo dài,...). Trong khi vai trò của các yếu tố này tham gia vào quá trình thoái hoá đất là khác nhau [2]. Vì vậy, thành lập bản đồ thoái hóa đất tiềm năng thực chất là giải bài toán phân tích đa chỉ tiêu (Multi Criteria Analysis - MCA).

MCA cung cấp cho người ra quyết định các mức độ quan trọng khác nhau của những chỉ tiêu, trong đó hầu hết sử dụng phương pháp phân tích thứ bậc (AHP) để xác định trọng số cho từng chỉ tiêu. Hạn chế chính của MCA là không có khả năng phân tích và biểu diễn dữ liệu không gian trên bản đồ [7]. Trong khi đó, hệ thông tin địa lý (GIS) lại có khả năng phân tích không gian và hố trợ thành lập bản đồ thoái hóa đất tiềm năng. Vì vậy, tích hợp GIS-MCA đánh giá và thành lập thoái hóa đất tiềm năng phục vụ cho quản lý, sử dụng đất hợp lý là hướng tiếp cận có tính khả thi cao. 
Lâm Đồng là tỉnh miền núi, độ cao trung bình $800-1.000 \mathrm{~m}$, diện tích tự nhiên 977.354,5 ha (chiếm 2,97\% diện tích cả nước và chiếm $17,92 \%$ diện tích vùng Tây Nguyên) [5]. Địa hình có sự phân hóa phức tạp, gồm đồi núi thấp, núi trung bình đến núi cao xen kẽ các thung lũng nhỏ bằng phẳng. Mức độ chia cắt sâu và độ dốc địa hình lớn (trên $60 \%$ diện tích có độ dốc $>25^{\circ}$ ); mạng lưới sông suối dày (từ $0,3-1,1 \mathrm{~km} / \mathrm{km}^{2}$ ); bậc thềm sông hẹp và dốc nên khả năng bồi đắp phù sa thấp. Khí hậu nhiệt đới gió mùa cao nguyên kết hợp với điều kiện địa hình đã mang lại cho Lâm Đồng một lượng mưa dồi dào (trung bình $1.750-3.150$ mm/năm), lượng mưa tập trung vào mùa mưa từ tháng V - XI (chiếm 80 - 90\% lượng mưa năm) [6]. Cùng với đặc điểm lớp phủ thổ nhưỡng đa dạng đã tiềm ẩn nguy cơ xảy ra các quá trình thoái hóa đất rất lớn nếu không có các biện pháp bảo vệ đất hợp lý trong quá trình sử dụng.

\section{Dữ liệu và phương pháp nghiên cứu và dữ liệu}

\subsection{Dũ̃ liệu sử dụng}

- Bản đồ đất tỉnh Lâm Đồng tỷ lệ 1:100.000 theo hệ thống phân loại của Việt Nam do Phân viện Quy hoạch và Thiết kế Nông nghiệp Miền Nam thành lập năm 2005, với 8 nhóm và 20 loại đất chính: Nhóm đất phù sa (26.594 ha); đất xám bạc màu (4.937 ha); đất đen (4.282 ha); đất đỏ vàng (859.087 ha); đất mùn vàng đỏ trên núi (31.741 ha); đất mùn trên núi cao (685 ha); đất thung lũng do sản phẩm dốc tụ (38.164 ha); đất xói mòn trơ sỏi đá (280 ha).

- Bản đồ địa mạo tỉnh Lâm Đồng tỷ lệ 1:100.000 do Viện Địa lý thành lập năm 2013, gồm 3 nhóm dạng địa hình và 25 dạng địa hình gồm: Nhóm dạng địa hình nguồn gốc nội sinh núi lửa (gồm 3 dạng địa hình); nhóm dạng địa hình nguồn gốc bóc mòn (16 dạng địa hình), nhóm dạng địa hình nguồn gốc tích tụ - xâm thực (6 dạng địa hình).

- Bản đồ vỏ phong hóa tỉnh Lâm Đồng tỷ lệ 1:100.000 do Viện Địa lý biên tập năm 2013, gồm 07 kiểu vỏ: Alferit, Feralit, Ferosialit, Sialferit, Sialit, Silicit và Saprolit vụn thô.

- Bản đồ xói mòn đất tiềm năng tỉnh Lâm Đồng tỷ lệ 1:100.000 do Viện Địa lý thành lập năm 2013 bằng phương trình mất đất phổ dụng của Wischmeier W.H. và Smith D.D. đề xuất.

- Bản đồ địa chất khoáng sản tỉnh Lâm Đồng tỷ lệ 1:100.000 do Liên đoàn Bản đồ Địa chất miền Nam thành lập năm 1993.

- Bản đồ nền địa hình tỉnh Lâm Đồng 1:100.000 do Trung tâm Thông tin Dữ liệu đo đạc và Bản đồ (Cục Đo đạc và Bản đồ Việt Nam) công bố năm 2002. Mô hình số độ cao (DEM) ASTER độ phân giải 30m do Cơ quan Hàng không Vũ trụ Mỹ (NASA) cung cấp miễn phí.

- Số liệu mưa, bốc hơi trung bình tháng và năm của các trạm Bảo Lộc, Liên Khương, Đà Lạt từ năm 1981 - 2013 do Trung tâm Khí tượng Thủy văn Quốc gia cung cấp.

\subsection{Phương pháp nghiên cứu}

Ứng dụng phương pháp tích hợp GISMCA để thành lập bản đồ thoái hóa đất tiềm năng tỉnh Lâm Đồng tỷ lệ 1:100.000 gồm các bước sau: (xem hình 1)

- Bước 1. Xác định mục tiêu và thu thập dũ̃ liệu: Trên cơ sở xác định mục tiêu và phạm vi của nghiên cứu, tiến hành thu thập và tổng hợp các thông tin, dữ liệu đầu vào, gồm các điều kiện địa chất, vỏ phong hóa, địa hình, thổ nhưỡng, thảm thực vật, khí hậu, thủy văn, hiện trạng sử dụng đất,... từ đó có cái nhìn tổng quan, những nhận định ban đầu để tiến hành bước tiếp theo.

- Bước 2. Lựa chọn, xác định trọng số các chỉ tiêu cho đánh giá thoái hóa đất tiềm 


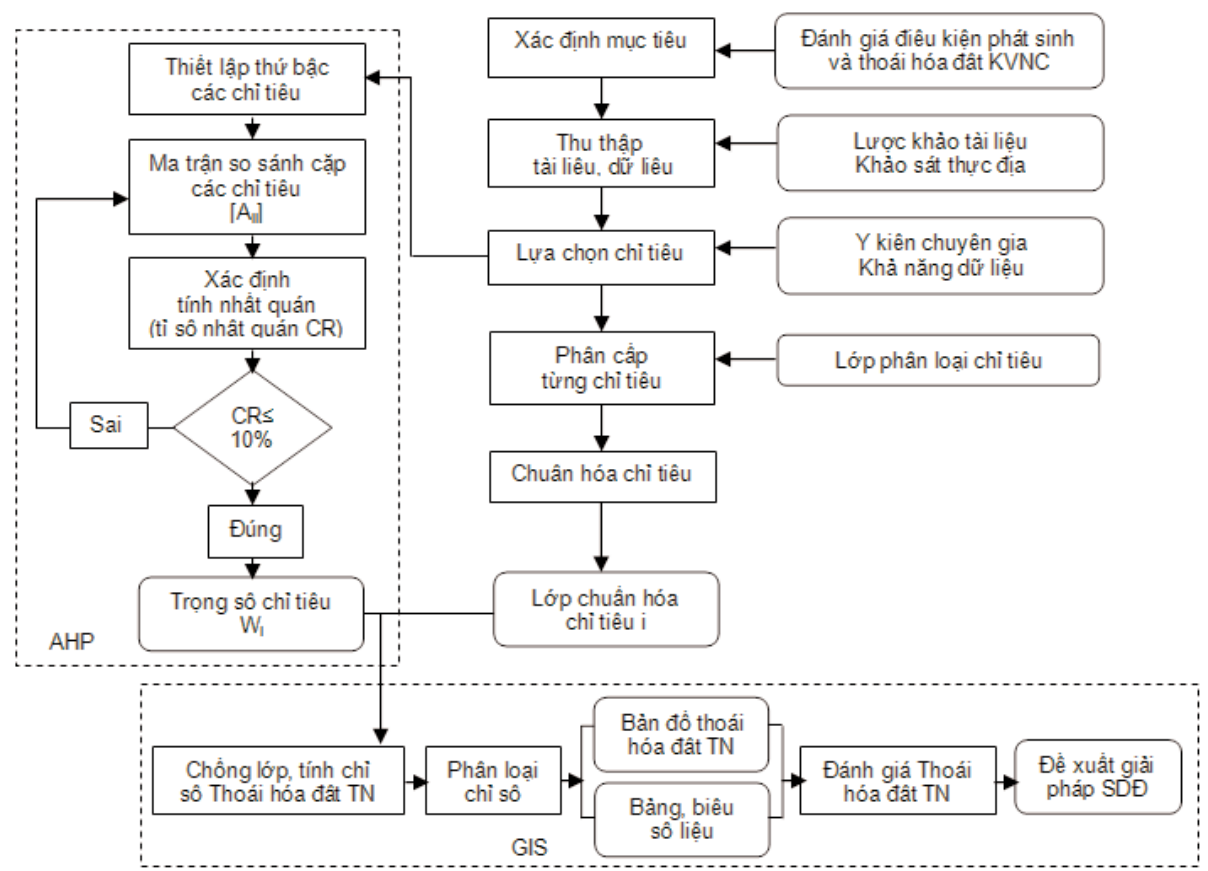

Hình 1: Mô hình GIS-MCA trong thành lập bản đồ thoái hóa đất tiềm năng

năng: Trên cơ sở kế thừa các nghiên cứu đi trước và tham vấn ý kiến chuyên gia, các chỉ tiêu được lựa chọn để đánh giá thoái hóa đất tiềm năng. Phân hạng mức độ tác động của từng chỉ tiêu để xác định trọng số của chúng theo phương pháp phân tích thứ bậc (AHP) (Saaty, 1980).

Việc xác định trọng số cho từng chỉ tiêu trong đánh giá thoái hóa đất bằng phương pháp AHP gồm các công việc như sau:

+ Thiết lập thứ bậc các chỉ tiêu đã chọn: Tạo tiền đề cho quá trình so sánh cặp giữa các chỉ tiêu. Một sơ đồ thứ bậc tương ứng được thể hiện như hình 2 (xem hình 2); trong đó, ở Cấp 1 thể hiện mục tiêu đánh giá thoái hóa đất tiềm năng; Cấp 2 thể hiện các tiêu chí chính trong đánh giá thoái hóa đất tiềm năng; Cấp 3 thể hiện các chỉ tiêu chi tiết của các tiêu chí chính; Cấp 4 thể hiện kết quả đánh giá thoái hóa đất tiềm năng bằng điểm của từng Pixel.

+ Thiết lập ma trận so sánh cặp các chỉ tiêu: Các chỉ tiêu được so sánh và cho điểm mức độ quan trọng với thoái hóa đất tiềm năng theo từng cặp. Công việc này đòi hỏi có sự tham vấn chuyên gia có kinh nghiệm trong lĩnh vực nghiên cứu. Điểm số so sánh cặp cuối cùng cho các chỉ tiêu sẽ được các chuyên gia thảo luâan và thống nhất. Trong đó, $\mathrm{A}_{\mathrm{ij}}$ là mức độ quan trọng của chỉ tiêu i so với chỉ tiêu j; chỉ tiêu j so với chỉ tiêu i: $A_{\mathrm{ji}}=$ $1 / A_{\mathrm{ij}} ; A_{\mathrm{ij}} \Leftarrow[1 / 9,1] \cup[1,9]$.

+ Tính tỷ số nhất quán (Consistency Ratio - CR) của ma trận so sánh: Trong các bài toán thực tế, không phải lúc nào cũng có thể xây dựng được quan hệ bắc cầu khi so sánh từng cặp chỉ tiêu. Chẳng hạn, phương án $A$ có thể tốt hơn phương án $B$, phương án $\mathrm{B}$ có thể tốt hơn phương án $\mathrm{C}$ nhưng không phải lúc nào phương án $A$ cũng tốt hơn phương án $\mathrm{C}$. Hiện tượng này gọi là sự không nhất quán. Sự không nhất quán là điều thực tế nhưng mức độ không nhất quán không nên quá nhiều vì khi đó nó thể hiện sự đánh giá không chính xác. AHP cung cấp cách đo lường bằng toán học để xác định mức độ không nhất quán của các nhận định chuyên gia thông qua tỷ số nhất 


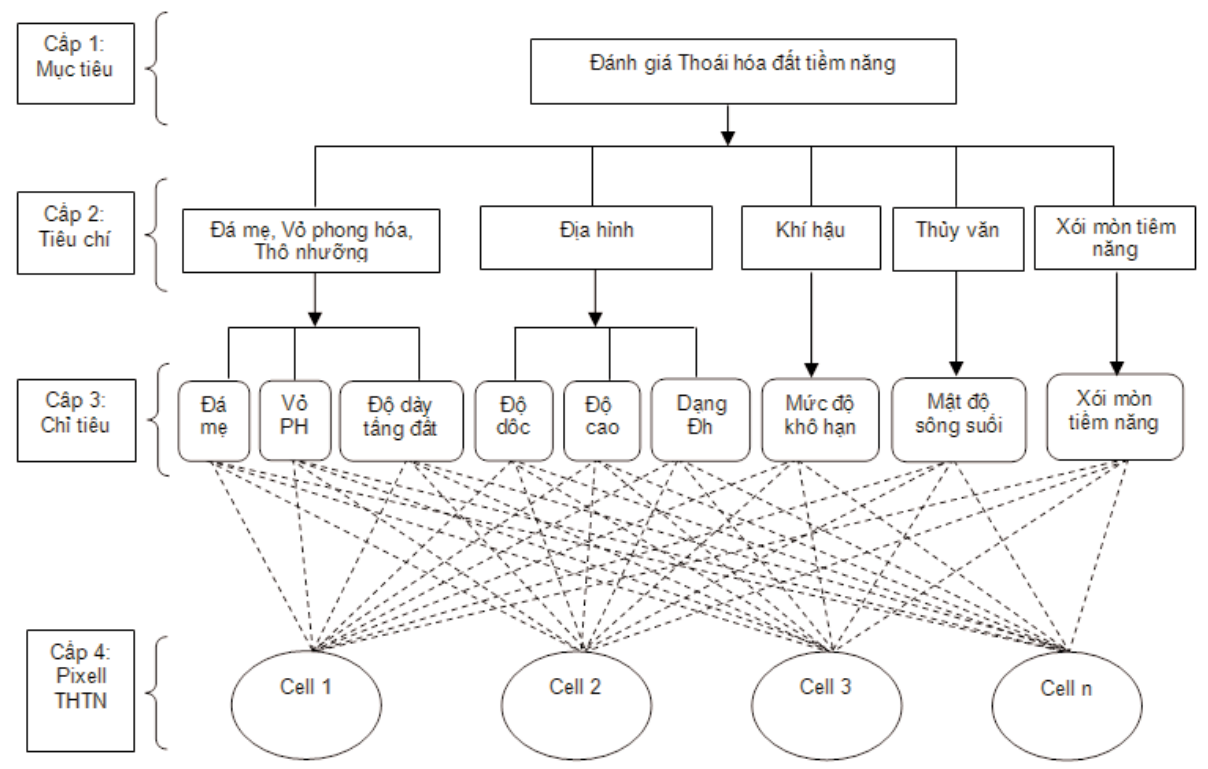

Hình 2: Cấu trúc thứ bậc AHP trong thành lập bản đồ thoái hóa đất tiềm năng

quán $(C R)$. Nếu $C R \leq 10 \%$ nghĩa là kết quả chấp nhận được, ngược lại $\mathrm{CR}>10 \%$ cần phải thẩm định lại các bước trước đó. Tỷ số nhất quán được tính theo công thức sau [8], [9]:

$$
\mathrm{CR}=\mathrm{CI} / \mathrm{RI}
$$

Trong đó: $\mathrm{Cl}$ là chỉ số nhất quán được tính theo công thức $\mathrm{Cl}=\left(\lambda_{\max }-\mathrm{n}\right) /(\mathrm{n}-1)$, với $\lambda_{\max }$ là giá trị trung bình của vector nhất quán; $n$ là số tiêu chí; RI (Random index) là chỉ số ngẫu nhiên hay giá trị trung bình của Cl.

Giá trị RI được xác định từ giá trị cho sẵn trong bảng (xem bảng 1) dưới đây:

+ Tính trọng số các chỉ tiêu $\left(\mathrm{W}_{\mathrm{i}}\right)$ : trên cơ sở ma trận so sánh cặp các chỉ tiêu $\left(A_{i j}\right)$, tính trọng số các chỉ tiêu (W) theo phương pháp Vector riêng (Eigen vector) [8], [9].

- Bước 3. Đánh giá thoái hóa đất tiềm năng: Ứng với mỗi chỉ tiêu xây dựng lớp thông tin chuyên đề trong GIS, chồng xếp các lớp thông tin chuyên đề, tính chỉ số thoái hóa đất tiềm năng (TN) ứng với từng vị trí. Phần mềm GIS sử dụng trong nghiên cứu là ArcGIS 10.1. Phương trình tính chỉ số TN như sau:

$$
T N=\sum_{i=1}^{n} W_{i}^{*} X_{i}
$$

Trong đó, TN là chỉ số thoái hóa đất tiềm năng; $\mathrm{W}_{\mathrm{i}}$ là trọng số chỉ tiêu $\mathrm{i} ; \mathrm{X}_{\mathrm{i}}$ là điểm của chỉ tiêu i; $n$ là số chỉ tiêu.

Kết quả thu được bản đồ với các giá trị số TN khác nhau trên mỗi pixel. Tiến hành phân cấp lại giá trị TN thành 4 cấp thoái hóa để thành lập bản đồ thoái hóa đất tiềm năng: Nhẹ (TN1), Trung bình (TN2), Mạnh (TN3), Rất mạnh (TN4). Mỗi cấp có các đặc điểm biểu hiện khác nhau về khu vực xuất hiện và các quá trình thoái hóa ưu thế. Ngưỡng để phân cấp các chỉ số thoái hóa đất tiềm năng được lựa chọn sau khi thực hiện xử lý thống kê giá trị số trong phần mềm ArcGIS, khoảng cách giữa các cấp được xác định theo công thức:

$$
\Lambda_{\mathrm{TH}}=\left(\mathrm{TN}_{\max }-\mathrm{TN}_{\min }\right) / 4 \text {. }
$$

\section{Kết quả và thảo luận}

3.1. Lựa chọn và phân cấp các chỉ tiêu xây dựng bản đồ thoái hóa đất tiềm năng Lâm Đồng 
Bảng 1: Bảng chỉ số ngẫu nhiên (RI)

\begin{tabular}{|c|c|c|c|}
\hline Chỉ tiêu thứ $\mathbf{n}$ & Giá trị RI & Chỉ tiêu thứ $\mathbf{n}$ & Giá trị RI \\
\hline 1 & 0,00 & 9 & 1,45 \\
\hline 2 & 0,00 & 10 & 1,49 \\
\hline 3 & 0,52 & 11 & 1,52 \\
\hline 4 & 0,89 & 12 & 1,54 \\
\hline 5 & 1,11 & 13 & 1,56 \\
\hline 6 & 1,25 & 14 & 1,58 \\
\hline 7 & 1,35 & 15 & 1,59 \\
\hline 8 & 1,40 & & \\
\hline
\end{tabular}

Nguồn: Saaty T.L., 1980 [8]

Kết hợp ý kiến chuyên gia, kinh nghiệm thực tiễn và kế thừa những nghiên cứu đi trước về đánh giá thoái hóa đất tiềm năng ở vùng Tây Nguyên [1], [2], [3]; nghiên cứu đã lựa chọn 09 chỉ tiêu gồm: Đá mẹ, kiểu vỏ phong hóa, độ dày tầng đất, dạng địa hình, độ dốc địa hình, độ cao địa hình, mức độ khô hạn, mật độ sông suối và xói mòn tiềm năng để đánh giá thoái hóa đất tiềm năng tỉnh Lâm Đồng. Từ đó tiến hành phân loại các chỉ tiêu theo các mức độ thoái hóa đất tiềm năng (4 cấp) và phân cấp giá trị điểm $X_{i}$ từ 1 - 4 điểm tương ứng với 4 cấp thoái hóa đất tiềm năng từ nhẹ đến rất mạnh của từng chỉ tiêu được lựa chọn (xem bảng 2).

\subsection{Tính toán trọng số các chỉ tiêu} phục vụ đánh giá thoái hóa đất tiềm năng

Phương pháp phân tích thứ bậc AHP cho phép so sánh tầm quan trọng tương đối của mỗi chỉ tiêu với mức độ thoái hóa đất tiềm năng theo từng cặp và lượng hóa theo thang đánh giá từ 1 - 9 điểm (xem bảng 3) [8], [9].

Kết quả tính tỷ số nhất quán $(\mathrm{CR})$ của ma trận so sánh cặp cho thấy, $\mathrm{CR}=0,014$ (< $0,1)$. Như vậy, ma trận so sánh cặp các chỉ tiêu đánh giá thoái hóa đất tiềm năng là nhất quán (xem bảng 4).

Trên cơ sở ma trận so sánh cặp các chỉ tiêu, tính toán trọng số của các chỉ tiêu được sử dụng cho đánh giá thoái hóa đất tiềm năng tỉnh Lâm Đồng theo phương pháp
Vector riêng. Kết quả tính toán cho thấy, trọng số của 9 chỉ tiêu được lựa chọn dao động từ 0,057 - 0,259. Trong đó, chỉ tiêu đá mẹ có trọng số lớn nhất đạt 0,259 ; chỉ tiêu mức độ xói mòn tiềm năng có trọng số thấp nhất là 0,057 (xem bảng 5).

\subsection{Kết quả thành lập bản đồ thoái hóa đất tiềm năng tỉnh Lâm Đồng}

Kết quả tính toán và thành lập bản đồ thoái đất tiềm năng tỉnh Lâm Đồng thể hiện 4 cấp như sau: (xem bảng 6, bảng 7 , hình 3)

- Cấp thoái hóa nhẹ (TN1): Diện tích khoảng 130.398,3 ha (chiếm 13,3\% diện tích tự nhiên); chủ yếu trên các loại đất nâu đỏ trên bazan, đỏ vàng trên đá phiến, tập trung nhều nhất ở khu vực phía Tây và Tây Nam của tỉnh, nhiều nhất ở huyện Cát Tiên (34.297,0 ha), Đạ Tẻh (33.099,0 ha).

- Cấp thoái hóa trung bình (TN2): Diện tích 534.608,1 ha (chiếm 54,7\%); phân bố trên các loại đất nâu đỏ và nâu vàng trên bazan, vàng đỏ trên macma axit. Tập trung nhiều nhất ở khu vực các huyện Bảo Lâm (104.925,6 ha), Lâm Hà (71.622,1 ha).

- Cấp thoái hóa mạnh (TN3): Diện tích 290.557,8 ha (chiếm 29,7\%); phân bố trên các loại đất vàng đỏ trên macma axit, đỏ vàng và mùn đỏ vàng trên đá phiến tập trung ở khu vực phía Nam, Đông Nam và Đông Bắc của tỉnh. Trong đó, huyện Di Linh có $78.280,8$ ha; Lạc Dương có $63.527,3$ ha; 
Bảng 2: Lựa chọn và phân cấp các chỉ tiêu xây dụng bản đồ thoái hóa đất tiềm năng Lâm Đồng

\begin{tabular}{|c|c|c|c|}
\hline Chỉ tiêu & Phân cấp chỉ tiêu & $\begin{array}{l}\text { Múc độ thoái } \\
\text { hóa tiềm năng }\end{array}$ & $\begin{array}{c}\text { Điểm } \\
(\mathrm{Xi})\end{array}$ \\
\hline \multirow{4}{*}{$\begin{array}{l}\text { 1. Đá } \\
\text { mẹ }\end{array}$} & $\begin{array}{l}\text { - Nhóm đá bazan tuổi Pleistocen giữa }\left(\mathrm{Q}_{1}{ }^{2}\right) ; \\
\text { - Nhóm trầm tích bở rời phù sa và dốc tụ }(\mathrm{Q})\end{array}$ & Yếu & 1 \\
\hline & $\begin{array}{l}\text { - Nhóm đá macma xâm nhập và đá biến chất; } \\
\text { - Nhóm đá trầm tích lục nguyên }\end{array}$ & Trung bình & 2 \\
\hline & - Nhóm đá bazan tuổi Pliocen - Pleistocen sớm $\left(\mathrm{N}_{2}-\mathrm{Q}_{1}{ }^{1}\right)$ có tầng laterit & Mạnh & 3 \\
\hline & - Nhóm đá bazan tuổi Pliocen - Pleistocen sớm $\left(\mathrm{N}_{2}-\mathrm{Q}_{1}{ }^{1}\right)$ có tầng bôxit & Rất mạnh & 4 \\
\hline \multirow{4}{*}{$\begin{array}{l}\text { 2. Vỏ } \\
\text { phong } \\
\text { hóa }\end{array}$} & $\begin{array}{l}\text { - Vỏ phong hoá alferit (AlFe) trên đá phun trào bazan Pleistocen giữa }\left(\beta Q_{1}{ }^{2}\right) \\
\text { - Vỏ phong hóa saprolit }(\mathrm{Sa})\end{array}$ & Yếu & 1 \\
\hline & - Vỏ phong hóa silicit (Si) & Trung bình & 2 \\
\hline & - Vỏ phong hoá sialit (SiAI) & Mạnh & 3 \\
\hline & $\begin{array}{l}\text { - Vỏ phong hoá sialferit (SiAlFe) } \\
\text { - Vỏ phong hoá ferosialit }(\mathrm{FeSiAl}) \\
\text { - Vỏ phong hoá alferit (AIFe) trên đá phun trào bazan Pliocen - Pleistocen sớm }\left(\beta \mathrm{N}_{2}-\mathrm{Q}_{1}{ }^{1}\right)\end{array}$ & Rất mạnh & 4 \\
\hline \multirow{4}{*}{$\begin{array}{l}\text { 3. Độ } \\
\text { dày } \\
\text { tầng } \\
\text { đất }\end{array}$} & $>100 \mathrm{~cm}$ & Yếu & 1 \\
\hline & $50-100 \mathrm{~cm}$ & Trung bình & 2 \\
\hline & $30-50 \mathrm{~cm}$ & Mạnh & 3 \\
\hline & $<30 \mathrm{~cm}$ & Rất mạnh & 4 \\
\hline \multirow{4}{*}{$\begin{array}{l}\text { 4. Dạng } \\
\text { địa } \\
\text { hình }\end{array}$} & $\begin{array}{l}\text { - Đồng bằng và trũng tích tụ trầm tích đầm lầy-aluvi } \\
\text { - Đáy trũng xâm thực và tích tụ bãi bồi của dòng chảy thường xuyên } \\
\text { - Vạt gấu tích tụ deluvi } \\
\text { - Pediment cao } 150-300 m \text { với quá trình rửa trôi bề mặt } \\
\text { - Pediment thung lũng với quá trình xâm thực và rửa trôi bề mặt }\end{array}$ & Yếu & 1 \\
\hline & $\begin{array}{l}\text { - Cao nguyên bazan trẻ với quá trình rửa trôi bề mặt (Q) } \\
\text { - Cao nguyên bazan với các quá trình rửa trôi bề mặt (N-Q) }\end{array}$ & Trung bình & 2 \\
\hline & $\begin{array}{l}\text { - Sườn bóc mòn tổng hợp với quá trình xói rửa } \\
\text { - Sườn bóc mòn với các quá trình xói rửa } \\
\text { - Sườn bóc mòn với các quá trình rửa trôi - xói rửa } \\
\text { - Thềm và đồng bằng tích tụ trầm tích aluvi } \\
\text { - Thềm và đồng bằng tích tụ trầm tích aluvi-proluvi } \\
\text { - Thềm và đồng bằng tích tụ-xâm thực trầm tích Neogen bị rửa trôi bề mặt }\end{array}$ & Mạnh & 3 \\
\hline & $\begin{array}{l}\text { - Sườn trọng lực với các quá trình trượt lở, đố lở } \\
\text { - Sườn trọng lực với các quá trình trượt lở, trôi trượt } \\
\text { - Sườn xâm thực - bóc mòn với các quá trình trôi trượt, trượt lở } \\
\text { - Sườn xâm thực - bóc mòn với quá trình xói rửa trôi trượt } \\
\text { - Sườn xâm thực với các quá trình trượt lở, đổ lở } \\
\text { - Sườn xâm thực với các quá trình trượt lở, trôi trượt } \\
\text { - Cao nguyên bazan cổ với các quá trình rửa trôi -xói rửa (N) } \\
\text { - Cao nguyên bóc mòn cao } 1000-1600 m \text { thoải, lượn sóng với quá trình rửa trôi bề mặt } \\
\text { - Cao nguyên bóc mòn cao } 1500-1800 m \text { lượn sóng, chia cắt mạnh với quá trình xâm thực } \\
\text { và rửa trôi bề mặt } \\
\text { - Bề mặt đỉnh cao } 800-1000 \text { m với quá trình rửa trôi - xói rửa } \\
\text { - Bề mặt đỉnh cao > } 1500 m \text { với quá trình rửa trôi - xói rửa }\end{array}$ & Rất mạnh & 4 \\
\hline \multirow{4}{*}{$\begin{array}{l}\text { 5. Độ } \\
\text { dốc } \\
\text { địa } \\
\text { hình }\end{array}$} & Độ dốc từ 0 - $8^{0}$ & Yếu & 1 \\
\hline & Độ dốc từ 8 - $15^{0}$ & Trung bình & 2 \\
\hline & Độ dốc từ 15 - 250 & Mạnh & 3 \\
\hline & Độ dốc > 250 & Rất mạnh & 4 \\
\hline \multirow{4}{*}{$\begin{array}{l}\text { 6. Độ } \\
\text { cao } \\
\text { địa } \\
\text { hình }\end{array}$} & Độ cao < 500m & Yếu & 1 \\
\hline & Độ cao 500 - 1.000m & Trung bình & 2 \\
\hline & Độ cao 1.000 - 1.500m & Mạnh & 3 \\
\hline & Độ cao > 1.500m & Rất mạnh & 4 \\
\hline
\end{tabular}




\begin{tabular}{|c|c|c|c|}
\hline \multirow{4}{*}{$\begin{array}{l}\text { 7. Mức } \\
\text { độ } \\
\text { khô } \\
\text { hạn }\end{array}$} & Khu vực có độ dài mùa khô $\leq 3$ tháng và không có tháng kiệt & Yếu & 1 \\
\hline & Khu vực có độ dài mùa khô 3 - 4 tháng và có 1 tháng kiệt & Trung bình & 2 \\
\hline & Khu vực có độ dài mùa khô 4 tháng và có 2 tháng kiệt & Mạnh & 3 \\
\hline & Khu vực có độ dài mùa khô 4 tháng và có 3 tháng kiệt & Rất mạnh & 4 \\
\hline \multirow{4}{*}{$\begin{array}{l}\text { 8. Mật } \\
\text { độ } \\
\text { sông } \\
\text { suối }\end{array}$} & $<0,25 \mathrm{~km}$ & Yếu & 1 \\
\hline & $0,25-0,5 \mathrm{~km}$ & Trung bình & 2 \\
\hline & $0,5-1,0 \mathrm{~km}$ & Mạnh & 3 \\
\hline & $>1,0 \mathrm{~km}$ & Rất mạnh & 4 \\
\hline \multirow{4}{*}{$\begin{array}{l}\text { 9. Xói } \\
\text { mò̀n } \\
\text { tiềm } \\
\text { năng }\end{array}$} & $<100$ tấn & Yếu & 1 \\
\hline & 100 - 500 tấn & Trung bình & 2 \\
\hline & $500-1.000$ tấn & Mạnh & 3 \\
\hline & $>1.000$ tấn & Rất mạnh & 4 \\
\hline
\end{tabular}

Bảng 3: Ma trận so sánh cặp các chỉ tiêu đánh giá thoái hóa đất tiềm năng

\begin{tabular}{|l|c|c|c|c|c|c|c|c|c|}
\hline & Đá mẹ & $\begin{array}{c}\text { Vỏ phong } \\
\text { hóa }\end{array}$ & $\begin{array}{c}\text { Độ dày } \\
\text { tâng đất }\end{array}$ & $\begin{array}{c}\text { Dạng địa } \\
\text { hình }\end{array}$ & Độ dốc & Độ cao & Khô hạn & $\begin{array}{c}\text { Mật độ } \\
\text { sông suối }\end{array}$ & $\begin{array}{c}\text { Xói mòn } \\
\text { tiềm năng }\end{array}$ \\
\hline Đá mẹ & 1 & 2 & 3 & 4 & 3 & 4 & 2 & 5 & 4 \\
\hline Vỏ phong hóa & $1 / 2$ & 1 & 2 & 3 & 2 & 3 & $1 / 2$ & 4 & 3 \\
\hline Độ dày tầng đất & $1 / 3$ & $1 / 2$ & 1 & 2 & 1 & 2 & $1 / 2$ & 3 & 2 \\
\hline Dạng địa hình & $1 / 4$ & $1 / 3$ & $1 / 2$ & 1 & $1 / 2$ & 1 & $1 / 3$ & 2 & 1 \\
\hline Độ dốc địa hình & $1 / 3$ & $1 / 2$ & 1 & 2 & 1 & 2 & $1 / 2$ & 3 & 2 \\
\hline Độ cao địa hình & $1 / 4$ & $1 / 3$ & $1 / 2$ & 1 & $1 / 2$ & 1 & $1 / 3$ & 2 & 1 \\
\hline Mức độ khô hạn & $1 / 2$ & 2 & 2 & 3 & 2 & 3 & 1 & 4 & 3 \\
\hline Mật độ sông suối & $1 / 5$ & $1 / 4$ & $1 / 3$ & $1 / 2$ & $1 / 3$ & $1 / 2$ & $1 / 4$ & 1 & $1 / 2$ \\
\hline Xói mòn tiềm năng & $1 / 4$ & $1 / 3$ & $1 / 2$ & 1 & $1 / 2$ & 1 & $1 / 3$ & 2 & 1 \\
\hline
\end{tabular}

Bảng 4: Các thông số sử dụng cho phân tích AHP

\begin{tabular}{|l|c|}
\hline \multicolumn{1}{|c|}{ Thông số } & Giá trị \\
\hline Giá trị riêng của ma trận $(\lambda \mathrm{max})$ & 9,163 \\
\hline Số lượng chỉ tiêu cho đánh giá $(\mathrm{n})$ & 9,000 \\
\hline Chỉ số nhất quán $(\mathrm{Cl})$ & 0,020 \\
\hline Chỉ số ngẫu nhiên $(\mathrm{RI})$ & 1,450 \\
\hline Tỷ số nhất quán $(\mathrm{CR})$ & 0,014 \\
\hline
\end{tabular}

Đức Trọng có 40.276,0 ha.

- Cấp thoái hóa rất mạnh (TN4): Diện tích 21.790,3 ha (chiếm 2,3\%); phân bố chủ yếu ở các huyện phía Nam và Đông Bắc của tỉnh như Di Linh: 15.408,0 ha; Đam Rông: $3.364,8$ ha. Các yếu tố gây thoái hóa nghiêm trọng ở đây là các loại đất vàng đỏ và đất mùn vàng đỏ trên macma axit, điều kiện khí hậu (Khu vực có mùa khô kéo dài trên 3 tháng và có trên 2 tháng kiệt) và độ
Bảng 5: Trọng số của các chỉ tiêu

\begin{tabular}{|l|c|}
\hline \multicolumn{1}{|c|}{ Chỉ tiêu } & Trọng số \\
\hline Đá mẹ & 0,259 \\
\hline Vỏ phong hóa & 0,156 \\
\hline Độ dày tầng đất & 0,099 \\
\hline Dạng địa hình & 0,057 \\
\hline Độ dốc của địa hình & 0,099 \\
\hline Độ cao của địa hình & 0,057 \\
\hline Mức độ khô hạn & 0,181 \\
\hline Mật độ sông suối & 0,035 \\
\hline Xói mòn tiềm năng & 0,057 \\
\hline
\end{tabular}

\section{Kết luận}

Mô hình tích hợp GIS-MCA góp phần quan trọng giúp giải quyết bài toán phân tích đa chỉ tiêu ứng dụng trong đánh giá và thành lập bản đồ thoái hóa đất tiềm năng. Trong đó, GIS đóng vai trò phân tích không gian, MCA với kỹ thuật phân tích thứ bậc (AHP) cho phép xác định trọng số của các chỉ tiêu và đánh giá mức độ ưu tiên của các chỉ tiêu đầu vào được lựa chọn. Mô hình 


\section{Bảng 6: Đặc điểm các cấp thoái hóa đất tiềm năng tỉnh Lâm Đồng}

\begin{tabular}{|c|c|c|}
\hline $\begin{array}{c}\text { Cấp } \\
\text { thoái hóa }\end{array}$ & Đặc điểm tụ̣ nhiên vùng xuất hiện & Các quá trình thoái hóa \\
\hline $\begin{array}{l}\text { Tiềm } \\
\text { năng } \\
\text { thoái } \\
\text { hóa } \\
\text { nhẹ } \\
\text { (TN1) }\end{array}$ & \begin{tabular}{|l|} 
- Cao nguyên bazan với các quá trình rửa trôi bề mặt \\
- Đồng bằng và trũng tích tụ đầm lầy - aluvi \\
- Pediment cao 150 - $300 \mathrm{~m}$ với quá trình rửa trôi bề mặt (ít) \\
- Vỏ phong hóa: Vỏ phong hóa dày (từ $10-20 \mathrm{~m})$ chủ yếu là \\
alferit trên đá phun trào bazan Pleistocen giữa (AlFe 2$)$; một \\
phần nhỏ các trầm tích Holocen trung - thượng, Holocen \\
thượng $\left(\mathrm{Q}_{2}^{2-3}, \mathrm{Q}_{2}{ }^{3}\right)$ \\
- Khu vực có độ dài mùa khô < 3 tháng và không có tháng kiệt \\
- Độ dốc phố biến 0 - 80 \\
- Đất: chủ yếu là $\mathrm{Fk}, \mathrm{Fs}$; rải rác $\mathrm{Fa}, \mathrm{Fu}, \mathrm{Fq}, \mathrm{Pf}, \mathrm{Pc}, \mathrm{D}$
\end{tabular} & $\begin{array}{l}\text { - Quá trình rửa trôi bề mặt thể hiện } \\
\text { là các trũng rất nông và thoải; } \\
\text { - Các quá trình khác yếu: } \\
\text { + Bạc màu yếu } \\
\text { + Ngập úng, glây hóa } \\
\text { + Xâm thực ngang và bồi lấp. }\end{array}$ \\
\hline $\begin{array}{l}\text { Tiềm } \\
\text { năng } \\
\text { thoái } \\
\text { hóa } \\
\text { trung } \\
\text { bình } \\
\text { (TN2) }\end{array}$ & $\begin{array}{l}\text { - Cao nguyên bazan trẻ với quá trình rửa trôi bề mặt } \\
\text { - Sườn bóc mòn tổng hợp với quá trình xói rửa } \\
\text { - Thềm và đồng bằng tích tụ trầm tích aluvi - proluvi; trầm tích } \\
\text { Neogen bị rừa trôi bề mặt } \\
\text { - Vỏ phong hóa: alferit trên đá phun trào bazan Pleistocen giữa } \\
\left(\mathrm{AlFe}_{1}, \mathrm{AlFe}_{2} \text { ) và silicit }(\mathrm{Si}) \text {. Vỏ phong hóa dày nhưng quá trình }\right. \\
\text { phong hóa không đồng đều, tạo nên các khối tảng có kích } \\
\text { thước khác nhau. } \\
\text { - Có độ dài mùa khô } 3 \text { - } 4 \text { tháng và có } 1 \text { tháng kiệt } \\
\text { - Độ dốc phổ biến: } 8 \text { - } 150 \\
\text { - Đất: chủ yếu là } \mathrm{Fk}, \mathrm{Fu}, \mathrm{Fa} \text {; rải rác } \mathrm{Fs}, \mathrm{Fd}, \mathrm{Fq}, \mathrm{D}, \mathrm{Py}, \mathrm{Pf}, \mathrm{Pb}\end{array}$ & $\begin{array}{l}\text { - Quá trình rửa trôi bề mặt chiếm } \\
\text { chủ yếu trên bề mặt các cao nguyên } \\
\text { và sườn; } \\
\text { - Quá trình xói rửa yếu xảy ra trên } \\
\text { các sườn có nguồn gốc bóc mòn } \\
\text { tổng hợp. Mật độ chia cắt tuy lớn } \\
\text { nhưng các máng xâm thực khá } \\
\text { nông và thoải với mặt cắt ngang } \\
\text { rộng. Vật liệu xói rửa được tích tụ } \\
\text { trong lòng các máng hoặc đưa } \\
\text { xuống chân sườn. }\end{array}$ \\
\hline $\begin{array}{l}\text { Tiềm } \\
\text { năng } \\
\text { thoái } \\
\text { hóa } \\
\text { mạnh } \\
\text { (TN3) }\end{array}$ & $\begin{array}{l}\text { - Cao nguyên bazan cô với các quá trình rưa trôi - xói rửa } \\
\text { - Cao nguyên bóc mòn cao } 1.000 \text { - } 1.600 \text { m thoải, lượn sóng } \\
\text { với quá trình rửa trôi bề mặt } \\
\text { - Cao nguyên bóc mòn cao } 1.500-1.800 \text { m lượn sóng, chia } \\
\text { cắt mạnh với quá trình xâm thực và rửa trôi bề mặt } \\
\text { - Sườn xâm thực - bóc mòn với các quá trình rửa trôi, xói } \\
\text { rửa, trôi trượt } \\
\text { - Vó phong hóa: Vỏ phong hóa Sialit mỏng }\left(\mathrm{SiAl}_{1}, \mathrm{SiAl}_{2}\right) \\
\text { - Có độ dài mùa khô } 4 \text { tháng và có } 2 \text { tháng kiệt } \\
\text { - Độ dốc phổ biến } 15 \text { - } 25^{0} \\
\text { - Đất: chủ yếu là } \mathrm{Fa}, \mathrm{Fs} \text {; rải rác } \mathrm{F} đ, \mathrm{Fu}, \mathrm{Ha}, \mathrm{Hs}\end{array}$ & $\begin{array}{l}\text { - Quá trình rửa trôi bề mặt mạnh với } \\
\text { các máng xâm thực nông và rộng tại } \\
\text { phần đỉnh các cao nguyên; } \\
\text { - Quá trình xói rửa với các máng } \\
\text { hẹp và sâu hơn phân bố gần chân } \\
\text { các cao nguyên, hình thành kêt von, } \\
\text { đá ong, đất bạc màu; } \\
\text { - Quá trình trôi trượt mạnh, xói mòn } \\
\text { khe rãnh trên các sườn dốc, nhiều } \\
\text { chỗ lộ tầng phong hóa dang dở hoặc } \\
\text { đá gốc. }\end{array}$ \\
\hline $\begin{array}{l}\text { Tiềm } \\
\text { năng } \\
\text { thoái } \\
\text { hóa } \\
\text { rất } \\
\text { mạnh } \\
\text { (TN4) }\end{array}$ & 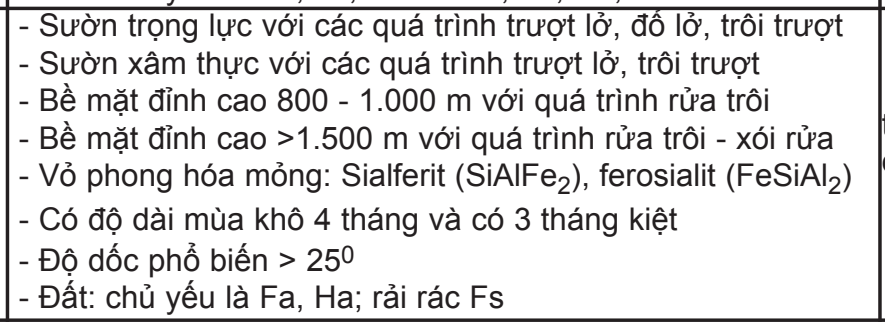 & $\begin{array}{l}\text { - Trượt lở, đổ lở và tích tụ trầm tích } \\
\text { theo sườn trên các sườn dốc và dốc } \\
\text { đứng; } \\
\text { - Xói mòn trơ xỏi đá. }\end{array}$ \\
\hline
\end{tabular}

Bảng 7: Diện tích các cấp thoái hóa đất tiềm năng tỉnh Lâm Đồng

\begin{tabular}{|l|c|c|c|}
\hline \multicolumn{1}{|c|}{ Cấp thoái hóa } & Khoảng giá trị TN & Diện tích (ha) & Tỷ lệ (\%) \\
\hline Tiềm năng thoái hóa nhẹ (TN1) & $1,01-1,67$ & $130.398,3$ & 13,3 \\
\hline Tiềm năng thoái hóa trung bình (TN2) & $1,67-2,33$ & $534.608,1$ & 54,7 \\
\hline Tiềm năng thoái hóa mạnh (TN3) & $2,33-2,99$ & $290.557,8$ & 29,7 \\
\hline Tiềm năng thoái hóa rất mạnh (TN4) & $2,99-3,65$ & $21.790,3$ & 2,3 \\
\hline \multicolumn{2}{|c|}{} & $\mathbf{9 7 7 . 3 5 4 , 5}$ & $\mathbf{1 0 0 , 0}$ \\
\hline
\end{tabular}




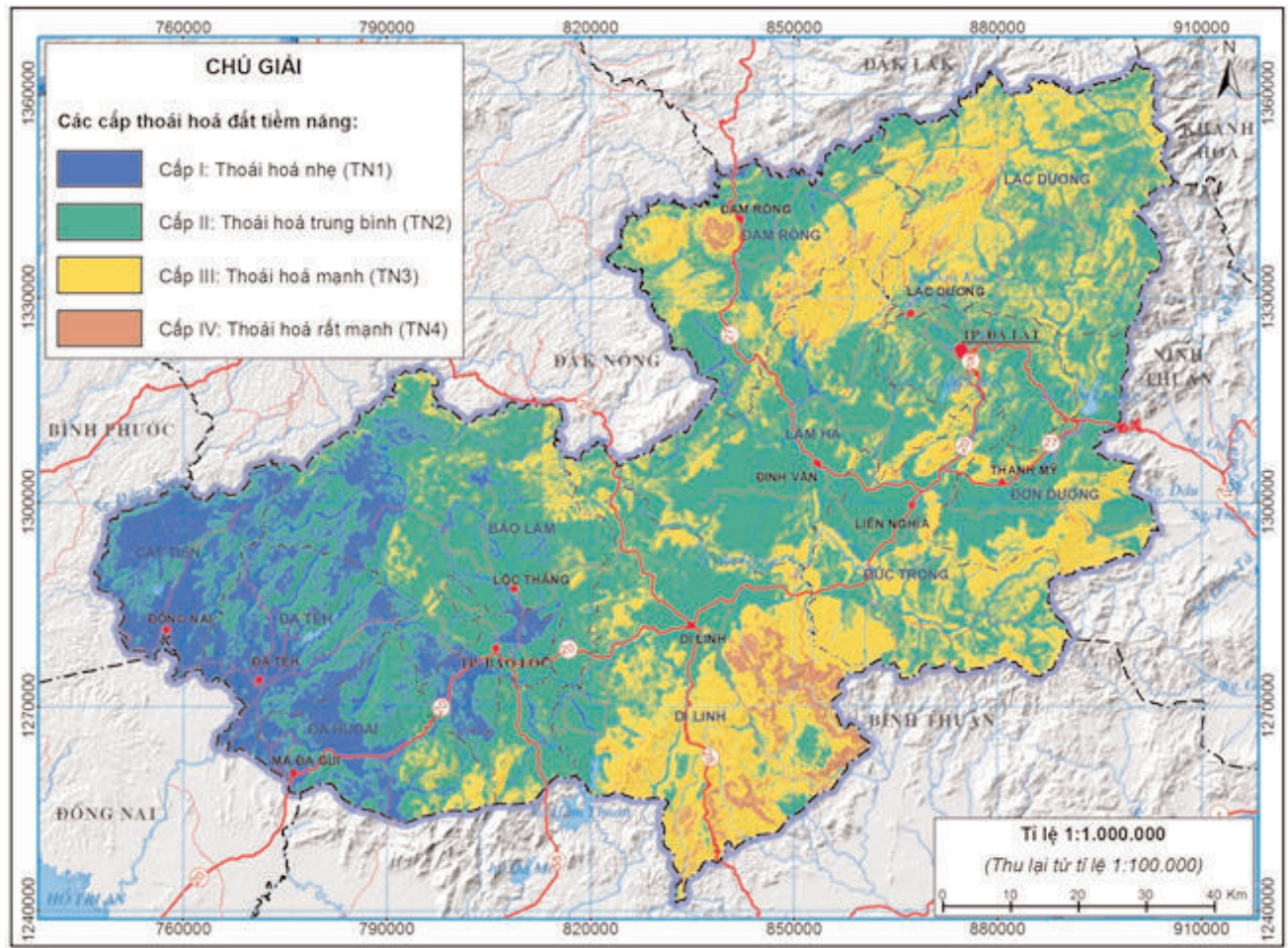

Hình 3: Bản đồ thoái hóa đất tiềm năng tỉnh Lâm Đồng

tích hợp này cho phép sử dụng kiến thức chuyên gia trong lĩnh vực nghiên cứu. Kết quả đánh giá các mức độ thoái hóa đất tiềm năng được thể hiện trực quan theo không gian lãnh thổ. Do vậy, dễ dàng hỗ trợ người ra quyết định giải quyết bài toán quy hoạch sử dụng đất và bố trí cây trồng hợp lý nhằm ngăn ngừa thoái hóa đất.

Kết quả ứng dụng mô hình tích hợp GISMCA trong đánh giá thoái hóa đất tiềm năng trên địa bàn tỉnh Lâm Đồng cho thấy:

- Diện tích đất có thoái hóa tiềm năng rất mạnh là 21.790,3 ha (chiếm 2,23\% diện tích tự nhiên). Các khu vực này cần ưu tiên bảo vệ và phát triển rừng;

- Diện tích đất có tiềm năng thoái hóa mạnh là 290.557,8 ha (chiếm 29,73\%). Các vùng này cần ưu tiên phát triển lâm nghiệp, nông lâm kết hợp có áp dụng các biện pháp chống xói mòn rửa trôi đất và lập kế hoạch cải tạo các vùng đất sản xuất nông nghiệp;
- Diện tích đất có tiềm năng thoái hóa trung bình là 534.608,1 ha (chiếm 54,70\%). Các khu vực này cần sử dụng các biện pháp bảo vệ đất trong sản xuất nông nghiệp, chống xói mòn bằng cây phủ đất, canh tác ruộng bậc thang và áp dụng các mô hình canh tác trên đất dốc (VAC, RVAC, SALT);

- Diện tích đất có tiềm năng thoái hóa tiềm năng nhẹ là 130.398,3 ha (chiếm 13,34\%). Đây là khu vực thuận lợi cho canh tác nông nghiệp, đặc biệt là cây ngắn ngày. Vì vậy, cần áp dụng các biện pháp bảo vệ trong sử dụng đất như xen canh, luân canh các loại cây trồng hợp lý.

Quá trình đánh giá bám sát điều kiện thực tiễn địa phương và có sự tham gia của nhiều nhà khoa học trong lính vực nghiên cứu, mang tính khả thi cao, có thể sử dụng kết quả này phục vụ cho quản lý sử dụng đất của địa phương. Mô hình này có thể ứng dụng để phục vụ cho công tác đánh giá 
thoái hóa đất tiềm năng trên các tỉnh khác thuộc địa bàn Tây Nguyên. Trong tương lai, cần tiếp tục ứng dụng mô hình trong nghiên cứu này cho các tỉnh thuộc các vùng sinh thái khác nhau để đánh giá và hiệu chỉnh mô hình phù hợp với công tác đánh giá thoái hóa đất tiềm năng cho các đơn vị cấp tỉnh trong cả nước. $O$

\section{Tài liệu tham khảo}

[1]. Lưu Thế Anh, 2012. Nghiên cứu xây dựng bản đồ thoái hóa đất tỉnh Đắk Lắk và Đắk Nông phục vụ sử dụng bền vững tài nguyên đất, Luận án Tiến sĩ Địa lý, Viện Địa lý, Hà Nội.

[2]. Lưu Thế Anh, 2014. Nghiên cứu tổng hợp thoái hóa đất, hoang mạc hóa ở Tây Nguyên và đề xuất giải pháp sử dụng đất bền vững, Báo cáo tổng hợp đề tài cấp Nhà nước thuộc Chương trình Tây Nguyên III, Viện Địa lý, Hà Nội.

[3]. Nguyễn Đình Kỳ, 1984. Nghiên cứu tổng hợp đất bazan thoái hóa Tây Nguyên, Báo cáo tổng hợp đề tài cấp Nhà nước thuộc chương trình Tây Nguyên II, Viện Địa lý, Hà Nội.
[4]. Nguyễn Đình Kỳ, 1999. Quan hệ địa lý phát sinh và thoái hóa đất trên các cao nguyên bazan nhiệt đới (lấy thí dụ Đông Bắc Việt $\mathrm{Nam})$, Tuyển tập các công trình nghiên cứu địa lý, NXB Khoa học và Kỹ thuật, Hà Nội.

[5]. Cục thống kê tỉnh Lâm Đồng, 2013. Niên giám thống kê tỉnh Lâm Đồng năm 2012, Đà Lạt.

[6]. Phân viện Quy hoạch và Thiết kế Nông nghiệp Miền Nam, 2005. Báo cáo thuyết minh bản đồ đất tỉnh Lâm Đồng kèm theo bản đồ đất tỷ lệ 1:100.000, Thành phố Hồ Chí Minh.

[7]. Malczewski J., 1999. GIS and Multicriteria decision Analysis, John Wiley \& Sons, Inc, New York, 408 p.

[8]. Saaty T.L., 1980. The analytic hierarchy process. McGraw- Hill, New York, 350p.

[9]. Saaty T.L. and Vargas L.G., 2001. Models, Methods, Concepts \& Applications of the Analytic Hierarchy Process, University of Pittsburugh, 334p. O

\section{Summary}

Intergration of GIS and multi-criteria analysis (MCA) for potential land degradation mapping of Lamdong province

Nguyen Thi Thuy, Luu The Anh,

\section{Institute of Geography Vietnam Academy of Science and Technology}

The potential land degradation map will provide important information as a basis for decision-making in the management and rational land use for preventing the land degradation processes. The potential land degradation correlates closely with natural factors that involved in soil forming processes as bedrocks/parent material, weathering crust, topography, hydrology, climate and vegetation. The role of each of these factors are not equal in case of causing land degradation. This is the basis for applying multi-criteria analysis (MCA) method in order to assess potential land degradation. The intergration of GIS-MCA approach has been used to solve the potential land degradation mapping of Lamdong province. The study result shows that the sligh potential degradation is $130,398.3$ hectares (accounting for $13.3 \%$ of natural area of the province); the average potential degradation is $534,608.1$ hectares (54.7\%); the strong potential degradation is $290,557.8$ ha $(29.7 \%)$; and very strong potential degradation is 21790.3 ha $(2.3 \%)$. 0 